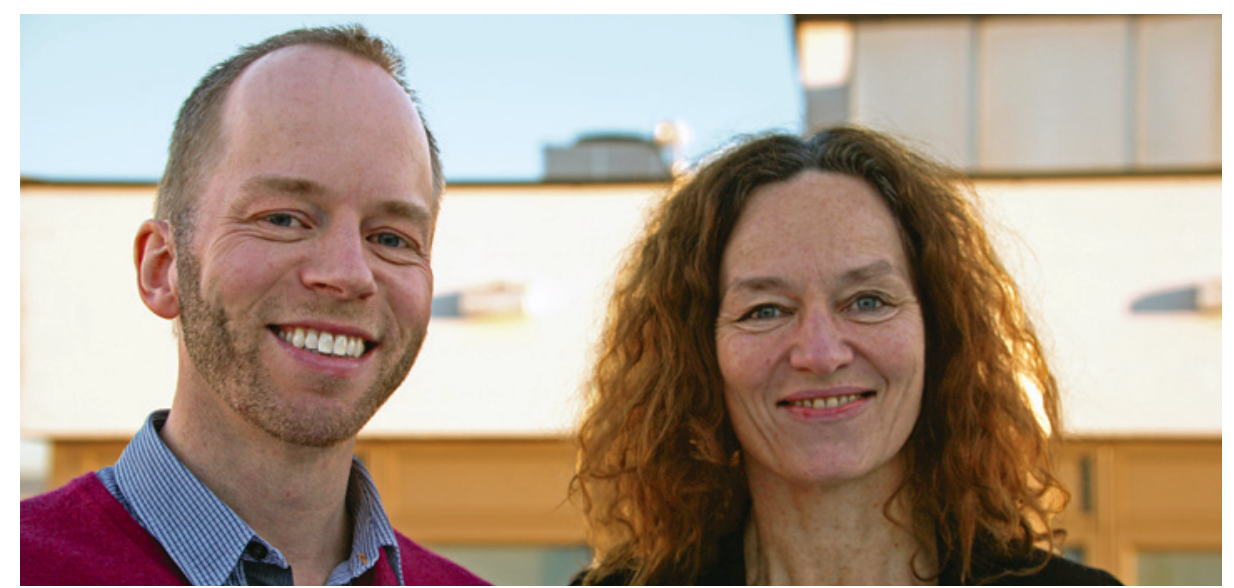

Pål Surén og Camilla Stoltenberg. Foto Torunn Gjerustad, Folkehelseinstituttet
Ordforklaringer

Autismespekterforstyrrelser (ASF): Samlebetegnelse på diagnosene innen autismespek teret, dvs. barneautisme, Aspergers syndrom, Retts syndrom, disintegrativ forstyrrelse, atypisk autisme og uspesifisert autisme.

Kumulativ insidens: Andelen av en populasjon som får en sykdom over et gitt tidsrom. Ved bruk av begrepet forutsettes det vanligvis at ingen er syke på forhånd og at populasjonen er statisk, dvs. at personer ikke beveger seg inn og ut av populasjonen.

Valideringsstudie: En studie for å vurdere hvorvidt diagnoser eller andre mål samsvarer med eksterne standarder eller referanser. Formålet er vanligvis å vurdere kvaliteten på diagnosene eller målene.

\title{
Autisme, AD/HD, epilepsi og cerebral parese hos norske barn
}

Forekomsten av autismespekterforstyrrelser, AD/HD, epilepsi

og cerebral parese hos norske barn er nå kartlagt.

Utviklingsforstyrrelser og nevrologiske lidelser er vesentlige årsaker til sykelighet og nedsatt funksjonsevne hos barn. Autismespekterforstyrrelser, $\mathrm{AD} / \mathrm{HD}$, epilepsi og cerebral parese er blant de vanligste årsakene til forsinket utvikling hos barn i Norge.

Etter at Norsk pasientregister (NPR) ble omgjort til et personentydig helseregister i 2008, er det mulig å kartlegge forekomsten av slike tilstander på landsbasis. Forskere ved Folkehelseinstituttet har i samarbeid med dette registeret beregnet forekomsten av autismespekterforstyrrelser, $\mathrm{AD} / \mathrm{HD}$, epilepsi og cerebral parese hos barn i alderen 0-11 år (1). Beregningene var basert på NPR-data fra perioden 2008-10. Estimert kumulativ insidens av de fire tilstandene steg med økende alder, og hos 11 -åringer var den $0,7 \%$ for autismespekterforstyrrelser, $2,9 \%$ for $\mathrm{AD} / \mathrm{HD}$, $0,9 \%$ for epilepsi og $0,3 \%$ for cerebral parese. Totalt var $4,3 \%$ av 11 -åringene registrert med én eller flere av disse tilstandene. Alle tilstandene var hyppigere hos gutter enn hos jenter, med en gutt-jenteratio på henholdsvis $4,3,2,9,1,2 \mathrm{og} 1,3$.

- En valideringsstudie av barn med autismespekterforstyrrelser indikerer at validiteten av autismediagnosene var høy for autismespekteret som helhet, sier Pål Surén. Av de undersøkte barna med autismediagnoser fra den norske spesialisthelsetjenesten $(n=32)$ ble nesten alle vurdert til å tilfredsstille DSMIV-kriteriene for autismespekterforstyrrelser (1). Valideringen pågår fortsatt, og antall undersøkte barn vil dermed bli høyere på sikt.

- Beregnet forekomst av autismespekterforstyrrelser og $\mathrm{AD} / \mathrm{HD}$ er noe lavere enn det som er rapportert fra Storbritannia og USA, men ellers avviker ikke Norge vesentlig fra andre rike land, sier Pål Surén.

- Funnene viser at det er en betydelig sykdomsbyrde blant norske barn som helhet og hvordan denne byrden i størst grad rammer gutter, kommenterer artikkelforfatterne.

\section{Forskergruppen}

Folkehelseinstituttet samarbeider med Norsk pasientregister om bruk av helseregisterdata i studier av autismespekterforstyrrelser, $\mathrm{AD} / \mathrm{HD}$, epilepsi og cerebral parese hos barn. NPR-data brukes i pågående delstudier av de fire tilstandene i den norske mor-og-barnundersøkelsen $(\mathrm{MoBa})$. Det pågår også registerbaserte studier av disse tilstandene, hvor data for hele den norske befolkningen brukes.

Pål Surén er doktorgradsstipendiat i autismestudien i MoBa-prosjektet. Inger Johanne Bakken deltar som forsker i studiene og er ansvarlig for tilretteleggingen av NPR-data. Camilla Stoltenberg, som er sisteforfatter, er prosjektleder for studiene av autisme og epilepsi i MoBa-undersøkelsen. De pågående studiene involverer mange forskere og internasjonale samarbeidspartnere. Forskergruppen arbeider med å bygge opp et system for å overvåke forekomsten av psykiatriske og nevrologiske sykdommer hos barn i Norge, og den aktuelle studien representerer et første skritt.

\section{Hanne Støre Valeur}

hanne.store.valeur@legeforeningen.no

Tidsskriftet

Litteratur
1. Surén P, Bakken IJ, Aase H et al. Autism spectrum disorder, ADHD, epilepsy, and cerebral palsy in Norwegian children. Pediatrics 2012; 130: e152-8.

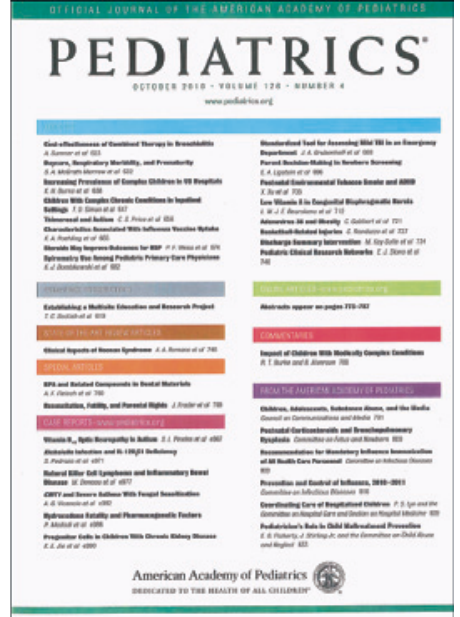

Artikkelen ble publisert i juliutgaven 2012 av tidsskriftet Pediatrics (http://pediatrics. aappublications.org/l, som er ett av de høyest rangerte pediatriske tidsskrifter 